\title{
A REVIEW ON CYCLAMEN SPECIES: TRANSCRIPTION FACTORS VS. PHARMACOLOGICAL EFFECTS
}

\author{
MIHAIELA CORNEA-CIPCIGAN ${ }^{1}$, DORU PAMFIL ${ }^{1}$, CRISTIAN RADU SISEA ${ }^{1}$, \\ CORNELIA PAULA GAVRIŞ', MARIA GRAÇA CAMPOS ${ }^{2,3}$ \\ and RODICA MǍRGǍOAN**
}

${ }^{1}$ University of Agricultural Sciences and Veterinary Medicine Cluj-Napoca,

Faculty of Horticulture, Department of Horticulture and Landscaping,

3-5 Mănăştur Street, 400372 Cluj-Napoca, Romania

${ }^{2}$ Observatory of Herb-Drug Interactions/ Faculty of Pharmacy, University of Coimbra,

Health Sciences Campus, Azinhaga de Santa Comba, Coimbra Portugal

${ }^{3}$ Coimbra Chemistry Centre (CQC, FCT Unit 313) (FCTUC) University of Coimbra, Rua Larga, Coimbra, Portugal

${ }^{4}$ University of Agricultural Sciences and Veterinary Medicine Cluj-Napoca,

Advanced Horticultural Research Institute of Transylvania, Cluj-Napoca, Romania

\begin{abstract}
The mechanism of floral mutation including double flowers in plant species can be explained by the ABCDE model which represents the relationship between MADS-box transcription factor genes and floral morphogenesis. The ornamental importance of Cyclamen led to the creation of double-flowered cultivars caused by the repression of AG-like gene expression in whorl 3. Modifications in these genes also influence the accumulation of different bioactive compounds depending on species and/or variety. In antiquity, cyclamen plants were recognized for their therapeutic qualities and later gained importance due to their content in saponins, which have been reported to exhibit anti-cancer, anti-inflammatory and antibacterial effects, and also to alleviate symptoms in acute rhinosinusitis patients. Furthermore, the extracts and isolated compounds are used as treatments in a wide range of diseases. In this review, we describe the transcription factors and their role in the development and $\mathrm{ABCDE}$ model formation of organs which led to the development of double-petal and fragrant varieties. Additionally, we describe the potential mechanisms of action underlying the therapeutic effects of saponin extracts against cancers and inflammatory disorders and their potential as a pharmacological agent in clinical studies.
\end{abstract}

Keywords: ABCDE model, cyclamin, MADS-box genes, medicinal properties, saponins, volatile compounds

The genus Cyclamen takes its name from the spherical tuber or the spiraled peduncle, shape that in Greek is called kyklos. Romans called it cyclaminis, and later, around the year 1700, the French botanist Tournefort named it Cyclamen (1). The 24 species (2) comprised in the genus Cyclamen are part of order Ericales, family Primulaceae, subfamily Myrsinoideae and are distributed in and around the Mediterranean region. Some of the species are frost resilient, some of which can bloom from late summer until late spring (Fig. 1).

In the genus Cyclamen, only Cyclamen persicum Mill. has been significantly used commercial- ly. Even though wild C. persicum Mill. plants usually bloom from winter to spring, the production period of commercially-grown plants depends on climate conditions and demands in each country (3).

Genus Cyclamen has been bred for more than 150 years. Initially, the focus was on plants with large flowers and shifted towards the selection of wide ranges of colors, based on the white and pink seen in wild $C$. persicum Mill.

At the same time, different petal shapes appeared, such as flattened, fringed and double. This development has increased the extent and intensity of leaf patterning by developing multiple sizes.

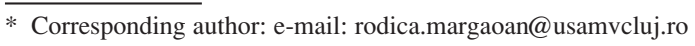


Nowadays, they are available in multiple growth types from Morel Diffusion S.A.S: Micro, Mini, Midi, Maxi, and Magnum. More recently, the focus was extended to re-introducing fragrance, which was lost in the quest for obtaining larger plants.

Germination and seedling survival are strongly correlated to environmental factors, such as temperature and precipitation. As a consequence, pigment responsible genes may influence physiological traits linked to drought and heat stress resistance $(5,6)$. Bioactive metabolites are produced by the response of plants to stress.

Plants respond to stress by producing a broad spectrum of bioactive specialized metabolites. Elicitors, such as jasmonates, trigger a complex signaling circuit leading to the activation of distinct metabolic pathways, even though, the transcription factors (TFs) involved in many metabolic pathways remain unknown. Two homologous jasmonate- inducible TFs of the basic helix-loop-helix (bHLH) family, namely TRITERPENE SAPONIN BIOSYNTHESIS ACTIVATING REGULATOR1 (TSAR1) and TSAR2, which direct triterpene saponin biosynthesis in Medicago truncatula Gaertu and Nicotiana tabacum L., have been reported (7-9). Also, in Arabidopsis, a different TF (i.e. MYC2) is responsible for the binding of sesquiterpene synthase gene promoters. This leads to an elevated release of volatile sesquiterpenes (10), proving to be an important aspect due to limited available data regarding TFs implicated in the activation of specialized terpene metabolite production.

In the case of Cyclamen species, habitat fragmentation, environmental degradation and tuber over-exploitation have exerted pressure on the native populations of these valuable ornamental species. Therefore, the entire genus Cyclamen is included in the Convention on International Trade in
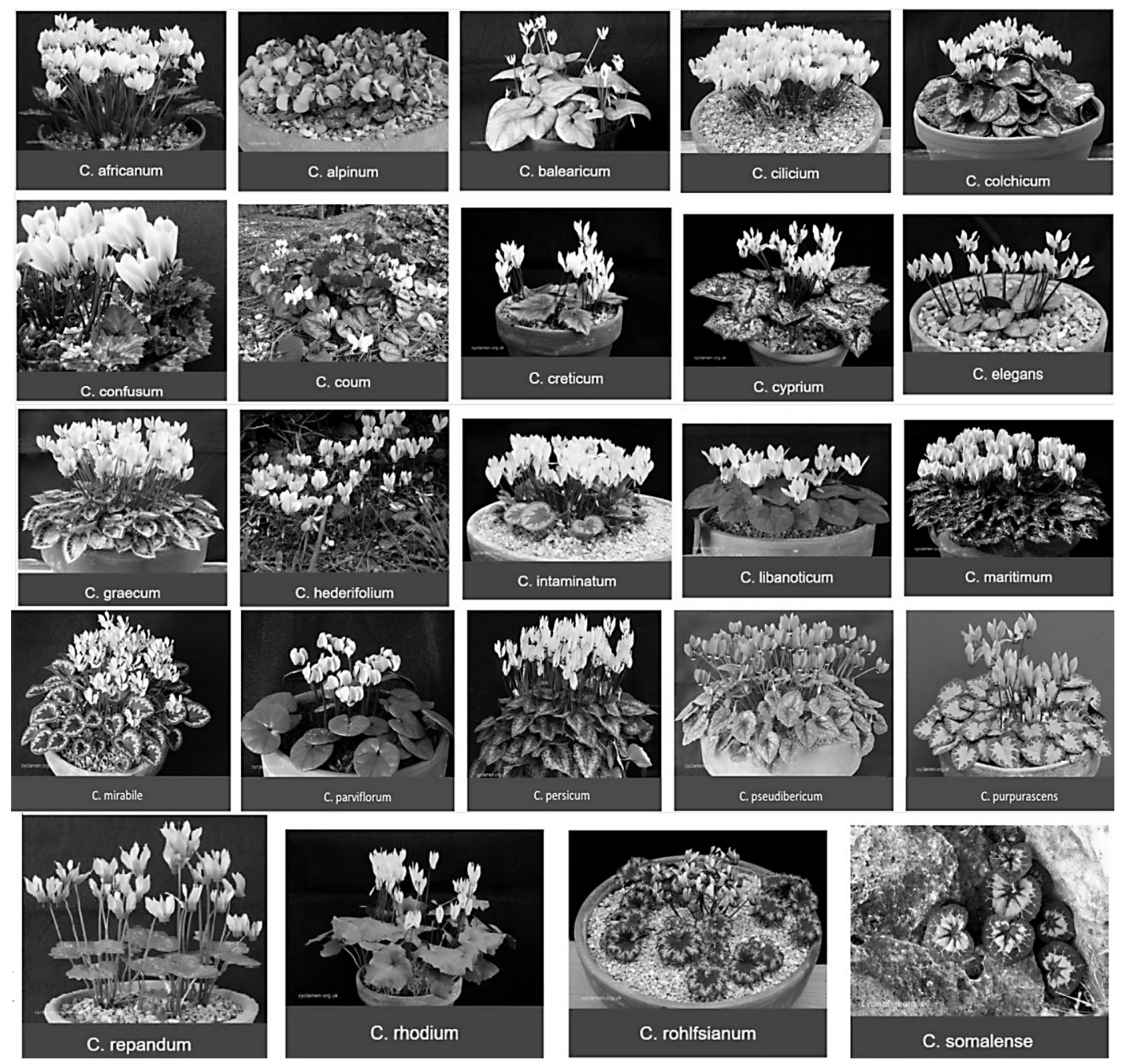

Figure 1. Genus Cyclamen known species (4). 


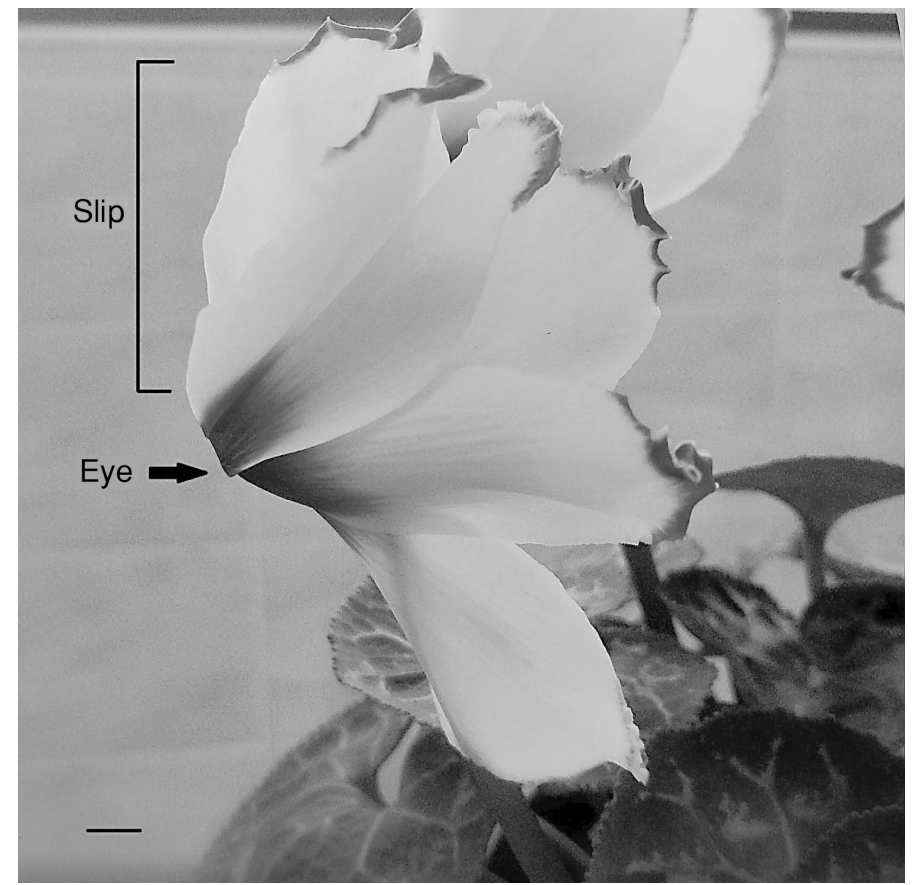

Figure 2(a). Flower characteristics of C. persicum cv. Victoria. Bar $=2 \mathrm{~cm}$; Expression patterns of cyclamen MADS-box genes in various tissues.

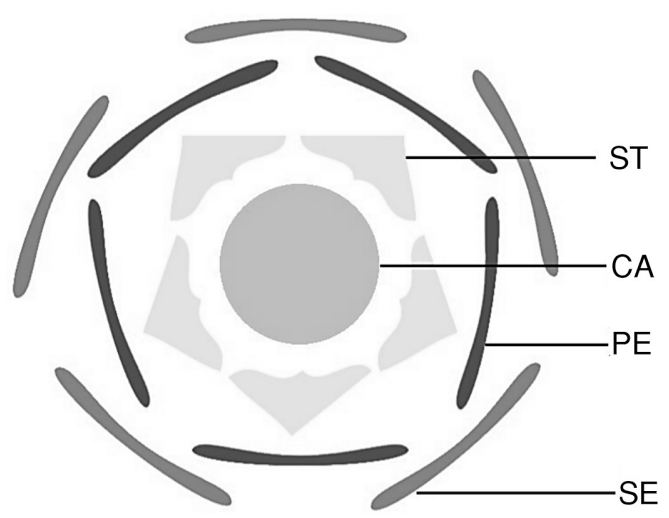

Figure 2(b). Flower characteristics of C. persicum cv. Victoria. Scheme of floral diagram showing the relative placement of floral organs. Lines and characters show each tissue. (SE) Sepals, (PE) Petals, (ST) Stamens, (CA) Carpel.

Endangered Species of Wild Fauna and Flora (CITES), while C. purpurascens Mill. is included in the International Union for Conservation of Nature (IUCN) Red List of Threatened Species (11), an important aspect due to the species significant characteristic, the fragrance.

The major pigments produced in Cyclamen flowers comprise flavonoids, carotenoids, chlorophylls, and betalains. Among flavonoids, anthocyanins range from red to purple and flavonol glycosides (quercetin and kaempferol glycosides) range from colorless or pale compounds. Anthocyanins and flavonol glycosides are widely distributed in many organs, especially in cyclamen flowers. Anthocyanin colors change with the presence of flavonol glycosides as co-pigments, resulting in a broad range of colors $(12,13)$. Also, it is well known that these above-mentioned molecules saponins, glycosides, tannins, resins, gums possess significant healing properties $(14,15)$.

The flowers of $C$. purpurascens Mill. and most C. persicum Mill. cultivars accumulate quercetin and kaempferol glycosides as major flavonols (16). In yellow-flowered Cyclamen, an interesting feature 
in color expression and pigmentation is observed, namely isosalipurposide (ISPP), which is the main pigment in petals but is also found in some vegetative organs (17). The pollen grains of $C$. pseudibericum Hildebr are radially symmetric, isopolar, tricolporate, spheroidal and circular in polar view. Their shape is comparatively similar to $C$. africanum Boiss \& Reut., C. mirabile Hildebr, C. neapolitanum and C. purpurascens. Furthermore, the aperture type of $C$. pseudibericum Hildebr pollen is similar to $C$. africanum Boiss \& Reut., C. hederifolium Aiton. and C. purpurascens Mill., but different from C. mirabile Hildebr, due to the fact that $C$. mirabile pollen is tetracolporate, while $C$. pseudibericum Hildebr pollen is tricolporate (18).

Floral features are particularly important in terms of production. The size of the petals and shape of the commercial plants vary from one species to another. Today, different genotypes are available with white, purple, red-carmine or yellow petals. Although diploid and tetraploid cultivars are available, the consumers show a preference for diploid F1 cultivars (2).

Several species have interesting horticultural features, such as $C$. purpurascens Mill., which emanates a powerful scent. While it is difficult to produce interspecific hybrid seeds in most of the crosses, hybrids can result from crosses between commercial $C$. persicum Mill. and several wildtypes, through in vitro culture (19-24).

Wild $C$. purpurascens Mill.. has small flowers with a purple slip and a deep purple eye, but $C$. purpurascens f. album Grey-Wilson, with a white slip and a white eye, is occasionally found in the wild. Neither form has been developed into commercial cultivars (2). However, their flowers emanate a sweet fragrance resembling rose, hyacinth or lily of the valley (25).

The biosynthesis of flower pigmentation proves to be an efficient system in elucidating gene expression and cell metabolism (3). Developing research into Cyclamens features and breeding techniques underline great reproduction possibilities, in addition to petal color and fragrance.

\section{Transcription factors (TFs) as key roles in regu- lating the expression of biosynthesis pathway genes}

Worldwide, Cyclamen is an important ornamental pot-flower. Various traits using molecular techniques in promoting breeding have been studied. They are commonly grown as pot flowers and recently produced as cut flowers. Hence, novel cultivars with distinctive flower morphologies, such as double flowers and fringed petals are desired by consumers and growers.

Wild C. Persicum Mill. has small flowers consisting of a white, pink or purple slip, which is the region excluding the eye, and a deep purple eye, meaning the region of the petal base. To better comprehend the significant features in Cyclamen species, for example, in $C$. persicum cv. Fuji Dark Violet, the flowers consist of a deep purple "eye" (the region of the petal base) and a purple "slip" (the region excluding the eye) with white edges (Fig. 2).

Cyclamen flowers, like those of many flowering plants, consist of four whorls. In the outermost whorl, there is a calyx consisting of five sepals. In whorl 2, there is a corolla consisting of five petals, with five stamens attached by short filaments in whorl 3. Whorl 4, in the center of the flower, contains one pistil with five fused carpels.

Modifications in flower shape, such as semidouble, double flowers and in distinct parts, like petals, sepals, give uniqueness, besides higher commercial value. In model plants, such as Arabidopsis thaliana (L.) Heynh. and Antirrhinum majus L., key TFs are responsible for identifying distinctive flower forms $(26,27)$.

TFs are proteins that control the rate of genetic information transcription from DNA mRNA by binding to a specific DNA sequence (28).

TFs possessing a DNA-binding region, known as MADS domain, are encoded by MADS-box family genes. These family genes involved in floral organ identity have been isolated from wide-ranging assortments of flowering plants. The advances in plant molecular genetics revealed that the mechanisms responsible for flower development have been highly conserved during evolution (29).

The function of MADS-domain proteins has been studied broadly in multiple organisms with the discovery that these proteins are involved in different plant developmental stages (30), in muscle development, neural signal transmission and tumor incidence in humans (31), cell survival and osmotic stress response in the yeast stationary phase (32).

Hindrance of conventional breeding is overcome by genetic engineering which can introduce novel traits in plants, such as flower color, fragrance, disease resistance, abiotic stress resistance, pest resistance, modification of flowering time and shape of flowers or other vegetative organs, was successfully accomplished in various genera, such as Chrysanthemum, Cyclamen, Petunia or Torenia, using diverse techniques, for instance, gene silencing (RNAi) and Chimeric REpressor gene-Silencing Technology (CRES-T) (33). 
Castelán-Muńoz et al., (2019) review how MADS-domain TFs play a distinct role in abiotic stress responses during seed development, vegetative growth, flowering, and root development. Among these abiotic factors, drought, salinity, low and high temperatures, as well as nutritional deficiencies greatly affect the plants' developmental stages $(35,36)$.

CRES-T is another important instrument that has lately been developed as a useful analysis method of plant TFs and for plant trait genetic manipulations. For CRES-T, a TF is converted into a strong repressor by an SRDX repression domain fusion, which afterward induces a loss-of-function phenotype.

The chimeric repressor dominantly suppresses the expression of target genes, even in the presence of redundant endogenous TFs, followed by TF lossof-function phenotype (37). CRES-T has been successfully utilized in modifying the shape of cyclamen (33), torenia (38), rose (39) and chrysanthemum (40).

Unique flower forms, such as double flower, have higher ornamental value than single-flowered phenotypes. Double flowers are characterized by several petal whorls, either by conversion of another floral organ into petals or excessive development. Aesthetic traits have long played significant importance, especially the development of double flowers in existing varieties $(41,42)$. Generally, the majority of double-flowered varieties were derived from single-flowered wild ancestors (43).

The induction of double-petal cyclamen flowers by introducing 35S:CpAG1-SRDX and 35S:CpAG2-SRDX into five petal cultivars has been achieved (38). Two transgenic cyclamen lines expressing 35S:CpAG1-SRDX produced doublepetal flowers, instead of stamens. Introducing of
35S:CpAG2-SRDX into a cultivar which lacks CpAG1 expression led to inducing of multi-petal flowers by conversion of stamens and carpel. Also, transgenic cyclamen lines with multi-petal flowers that harbor 35S:CpAG1-SRDX and 35S:CpAG2SRDX in a five petal cultivar, were produced. Therefore, rose-like flowers can be obtained by the expression of two chimeric AG repressors in cyclamen WT. Also, even though CpAG1 and CpAG2 have similar protein functions their roles in whorl 3 and whorl 4 remain distinctive.

Mutations occur in homeotic genes that encode TFs which control the development of distinct parts identity and exhibit the conversion of one body part into another. These mutations have been observed in A. thaliana (L.) Heynh. in determining not only flowering transition but also meristem specification, seed, root and fruit ripening, respectively. Their function has been widely studied and summarized in several outstanding reviews (39-45). The development of homeotic mutant flowers is made by mutation of ABCDE genes (27, 52) (Fig. 3).

Based on floral organ modifications from the quartet models $(27,53)$, A-class genes such as APETALA1, in Arabidopsis, and E-class genes are responsible for the development of sepals in the first floral whorl. B-class genes such as APETALA3 and PISTILLATA, along with A and E-class genes lead to petal formation in the second whorl. $\mathrm{B}, \mathrm{C}$ and $\mathrm{E}$ class genes, such as AG, merge in function to specify stamens in whorl 3. C and E-class genes singularly specify carpel identities in the fourth whorl. Coming along, D-class function genes are required for ovule development. Cloning of ABCDE homeotic genes in Arabidopsis revealed the encoding of MADS-box TFs (38). Therefore, transformation of one organ type into another is achievable via homeotic genes.

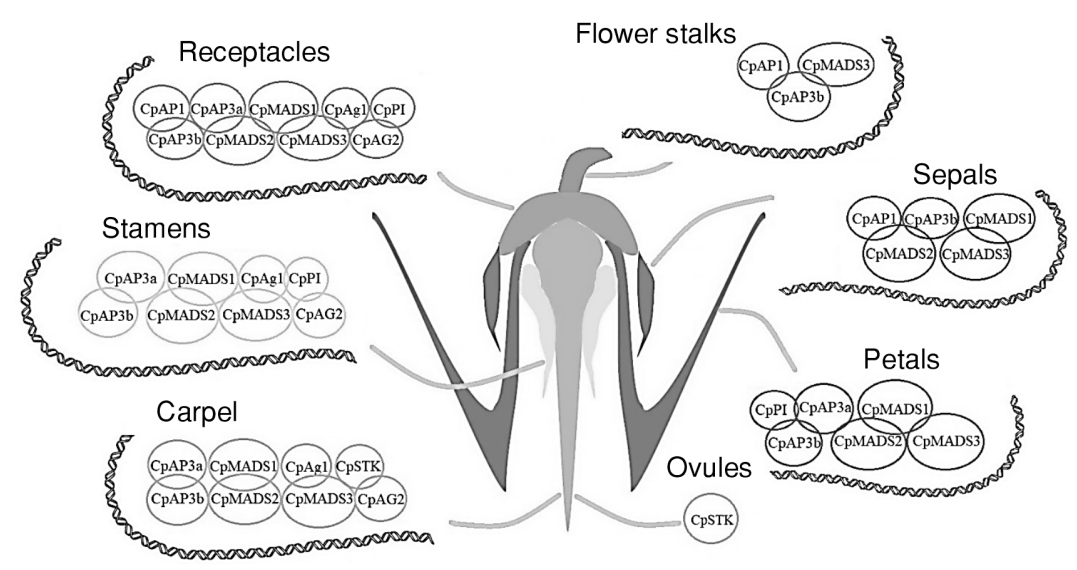

Figure 3. ABCDE model in Cyclamen (frontal view) and genes expression patterns in various tissues. 
In Arabidopsis, A-class gene is AP1 required for floral meristem identity, B-class genes are AP3 and PISTILLATA (P1) and C-class gene is AG. The $\mathrm{C}$-class gene is required for determining the floral meristem, as well as male and female organogenesis. The D-class genes are SEEDSTICK (STK), SHATTERPROOF1 (SHP1) and SHP2 and E-class genes are represented by SEPALLATA1 (SEP1), SEP2, SEP3, and SEP4. Regarding the interaction of $\mathrm{D}$ and E-class proteins is they specify ovule identity and E-class genes appear to be redundant when it comes to determining the identity of sepals, petals, stamens, and carpels. For instance, the flowers of Arabidopsis ag mutants have no stamens or carpels, therefore losing the ability to terminate meristematic activity, resulting in a frequent structure of sepal with tens of petals $(54-61,38)$.

In Cyclamen, the single A-class gene, CpAP1 is expressed in sepals, receptacles, flower stalks and slightly in petals. The B-class genes: CpPI is expressed in petals, stamen and receptacles, CpAP3a is expressed in petals, stamen, carpels and receptacles, and $\mathrm{CpAP} 3 \mathrm{~b}$ is expressed in sepals, petals, stamen, carpels, receptacles and flower stalks. From the C-class AGAMOUS the CpAG1 and Cp AG2 genes are expressed in stamen, carpels and receptacles. The $\mathrm{D}$-class gene is represented by CpSTK which has the same expression pattern as in Arabidopsis, namely carpels. The E-class genes in Arabidopsis are expressed in sepals, petals, carpel and stamen, whereas in cyclamen along with expression patterns from Arabidopsis, CpMADS1 is also expressed in receptacle and flower stalks and CpMADS2 in receptacle. The CpMADS3 gene encodes a $>50 \%$ identical protein to FLOWERING LOCUS C (FLC), which is expressed in all tissues in cyclamen, compared to Arabidopsis where it was regarded as a flowering repressor because it is not expressed in inflorescence tissues (Table 1).

Multiple interspecific hybrids, allodiploids (AB) and allotetraploids (AABB) have been obtained, which release monoterpene alcohols, sesquiterpene alcohols, phenylpropanoids/benzenoids, and the fragrance rose oxide (monoterpene) with a similar scent to $C$. purpurascens Mill. (25). Nowadays, breeders are trying to introduce fragrance in other varieties, but with few positive results, due to cross-incompatibility. The increasing demand for scented cyclamen cultivars led to the creation of scented yellow cyclamen. The crossing of allotetraploid from $C$. persicum "Golden Boy" $(\mathrm{AA}) \times C$. purpurascens $(\mathrm{BB})$ resulted in pink cultivars with volatiles and perfumes similar to $C$. purpurascens Mill.

This proves to be an efficient transformation, due to the increasing demand in varieties with highly ornamental traits, such as color or perfume, especially because $C$. purpurascens Mill. represents the original fragrant specie, being the most scented compared to the other species of the genus.

The main purpose of flower pigmentation is attracting pollinators, meaning that flower color patterns are easily identifiable against their background. However, flower color is not perceived equally by all pollinators. For example, hummingbirds distinguish red flowers, but to bees, they are colorless (62). It can be foreseen that mutational inactivation of several target genes can efficiently

Table 1. TFs in Cyclamen and Arabidopsis.

\begin{tabular}{|c|c|c|c|c|c|}
\hline \multirow{2}{*}{$\begin{array}{c}\text { Class } \\
\text { genes }\end{array}$} & \multicolumn{2}{|c|}{ Genes } & \multicolumn{2}{c|}{ Expression pattern } & $\begin{array}{c}\text { Amino acid sequence } \\
\text { sharing to Arabidopsis }\end{array}$ \\
\cline { 2 - 5 } & Cyclamen & Arabidopsis & Cyclamen & Arabidopsis & $60 \%$ \\
\hline \multirow{3}{*}{ A } & CpAP1 & AP1 & SE, R, FS, mP & FS, SE & - \\
\cline { 2 - 6 } & CpPI & PI & P, ST, R & P, ST & P, ST \\
\cline { 2 - 6 } & CpAP3a & AP3 & P, ST, C, R & P, ST & $48 \%$ \\
\hline \multirow{2}{*}{ C } & CpAP3b & AP3 & SE, P, ST, C, R, FS & ST, C, R & $71 \%$ \\
\cline { 2 - 6 } & CpAG2 & AG & ST, C, R & ST, C, R & $68 \%$ \\
\hline \multirow{2}{*}{ D } & CpSTK & STK & ST, C, R & C & $60 \%$ \\
\hline \multirow{2}{*}{ E } & CpMADS1 & SEP2 & SE, P, ST, C, R, FS & P, ST, C & $66 \%$ \\
\cline { 2 - 6 } & CpMADS2 & SEP3 & SE, P, ST, C, R, & P, ST, C & $72 \%$ \\
\hline \multirow{2}{*}{ Other } & CpMADS3 & FLC & SE, P, ST, C, R, FS, L, LS & NE & - \\
\cline { 2 - 5 } & CpACT & ACT & SE, P, ST, C, R, FS, L, LS & NE & - \\
\hline
\end{tabular}

Note: SE, Sepal; P, Petal; ST, Stamen; C, Carpel; R, Receptacle; FS, Flower Stalk; L, Leaf; LS, Leaf Stem, NE, not expressed 
<smiles>O=Cc1ccccc1</smiles>

Benzaldehide MW: $106.124 \mathrm{~g} / \mathrm{mo}$<smiles>OCc1ccccc1</smiles>

Benzyl alcohol

Methyl benzoate

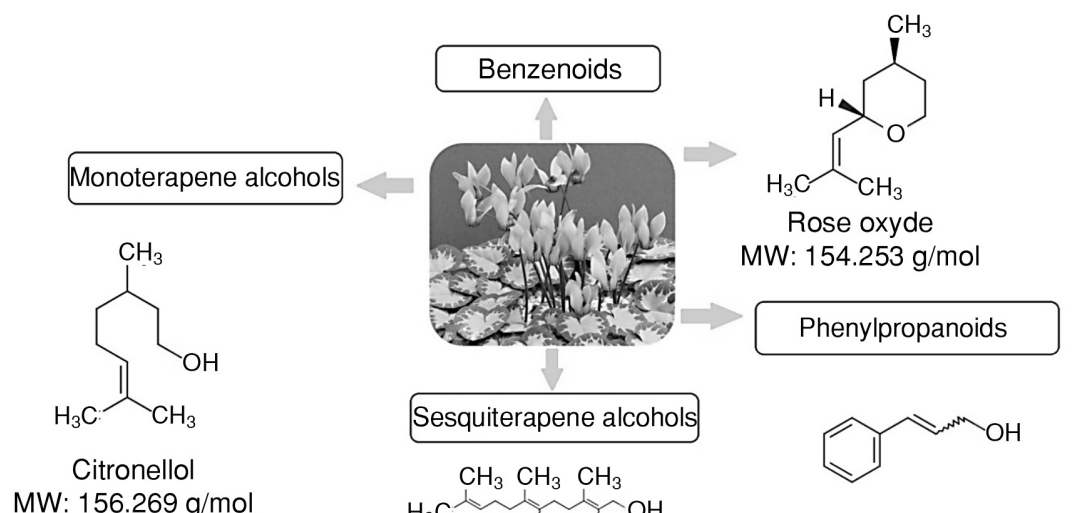

MW: $156.269 \mathrm{~g} / \mathrm{mol}$<smiles>CC(C)=CCC(C)=CCO</smiles><smiles>CC(C)CCC(C)CCC(C)O</smiles>

Cinnamic alcihol

Farnesol

MW: $222.372 \mathrm{~g} / \mathrm{mol}$

Geraniol

MW: $154.253 \mathrm{~g} / \mathrm{mol}$<smiles>CC(C)C1CC[C@@H](C)C[C@H]1O</smiles><smiles>CC(C)CCCC(C)CCCC(C)CCO</smiles>

2,3 Dihydrofarnesol MW: $224.388 \mathrm{~g} / \mathrm{mol}$ MW: $134.178 \mathrm{~g} / \mathrm{mol}$

MW: $156.269 \mathrm{~g} / \mathrm{mol}$<smiles>C=CC(C)(O)CCC=C(C)C</smiles>

Linalool<smiles>OCCC1CCCCC1</smiles>

Cinnamic aldehyde MW: $132.162 \mathrm{~g} / \mathrm{mol}$

$\mathrm{HO}$<smiles>CCCCc1ccccc1</smiles>

Hydeocinnamic alcohol MW: $136.194 \mathrm{~g} / \mathrm{mol}$

MW: $154.253 \mathrm{~g} / \mathrm{mol}$

Figure 4. Volatile compounds in the flowers of $C$. purpurascens Mill.

change and ultimately predict the type of pollinators, with consequences in speciation and genetic isolation (63).

For instance, bumblebee's preference for color can be influenced by floral scent (64). A hint in nectar quality is given by flower pigmentation (65), and pollinator choices are affected by nectar rewards, respectively $(66,67)$. The scent has not been regarded as an important breeding characteristic due to the fact that most of the $C$. persicum Mill. cultivars release a powdery or weak woody scent. Recently it became a field of interest due to the presence of sesquiterpene hydrocarbons in C. purpurascens Mill. which releases a sweet fragrance resembling hyacinth, rose or lily of the valley (25) (Fig. 4). The flowers of $C$. purpurascens Mill. emit monoterpene alcohols, sesquiterpene alcohols, phenylpropanoids, benzenoids, and rose oxide. Among aromatic compounds, phenylpropanoids are major volatiles and benzenoids are minor volatiles $(25,68)$. Most of these sesquiterpene alcohols, such as farnesol, have been reported to exhibit anti-cancer and anti-inflammatory effects, and also alleviate allergic asthma, gliosis and edema (69). These can lead to the discovery of new natural drugs with potential uses as anticancer agents.

The major breeding goals are the creation of novel flower forms in ornamentals, increasingly defining the commercial value by its unique asset. 
Floral organs are determined by five classes of homeotic genes, namely A, B, C, D, and E, whereas developing new varieties comes with the modification of these genes. Therefore, chimeric repressor constructs may save time in breeding novel varieties with double- and multi-petals, based on already existing cultivars with valuable traits such as perfume, eye-catching colors and ruffled petals. Usage of these TFs and other multiple strategies like hybridization, genetic engineering, mutation, and polyploidy, results in the possibility of developing unique flower varieties.

The examination of how such paralogous TFs exert their distinct functions, probably with slight different binding-site sequence peculiarities, will prove to be an attractive topic for future research.

\section{General medicinal importance and pharmacog- nosy}

Many plant extracts represent a source of secondary metabolites with different biological and pharmacological properties and play a therapeutic role in the human organism (70). The medicinal use of Cyclamen is known since antiquity by Egyptians, Greeks and Romans.

Investigating the chemical composition of several Cyclamen species, various authors have reported the presence of triterpene saponins and glycosides (71), phenolic and polyphenolic components (15) (anthocyanins, flavonoids (72)), a piperidine alkaloid and sterols (73).
Saponins (from the Latin word "sapo", or soap), are a class of high molecular weight secondary metabolites, characterized by a carbon skeleton derived from a 30-carbon 2,3-oxidosqualene precursor. They can be classified in steroidal $\left(\mathrm{C}_{27}\right)$ or triterpenoid $\left(\mathrm{C}_{30}\right)$ saponins, based on their carbon nucleus (aglycone). Sugar residues are linked to the aglycone, conferring an amphiphilic nature to these molecules, which is significant for their biological activities of these glycosides (74). They comprise a large variety of molecules that have multiple potential applications in pharmacology, for instance, antiinflammatory, antibacterial, immunoadjuvant, antiplatelet, antitumoral, hypocholesterolemic, antiHIV, insecticide, fungicide, anti-leishmanial bioactivity (75), as well as in food and cosmetics (76).

Even though they are considered to be toxic, the leaves of $C$. persicum Mill. are used as food in Palestine and other Middle East countries to make Za'amatoot. The leaves are filled with rice and meat, made into rolls before cooked and eaten with yogurt (77).

Saponins and saponin-rich extracts are used in the food industry as foaming agents for beverages, as detergents. They are known to cause hemolysis, by complexing plasma membrane sterols and by increasing membrane permeability. This asset of affecting membrane integrity is partially related to their antimycotic and antimicrobial activities. In plants, saponin functions are usually associated with resistance against pathogens, mostly fungi (78).

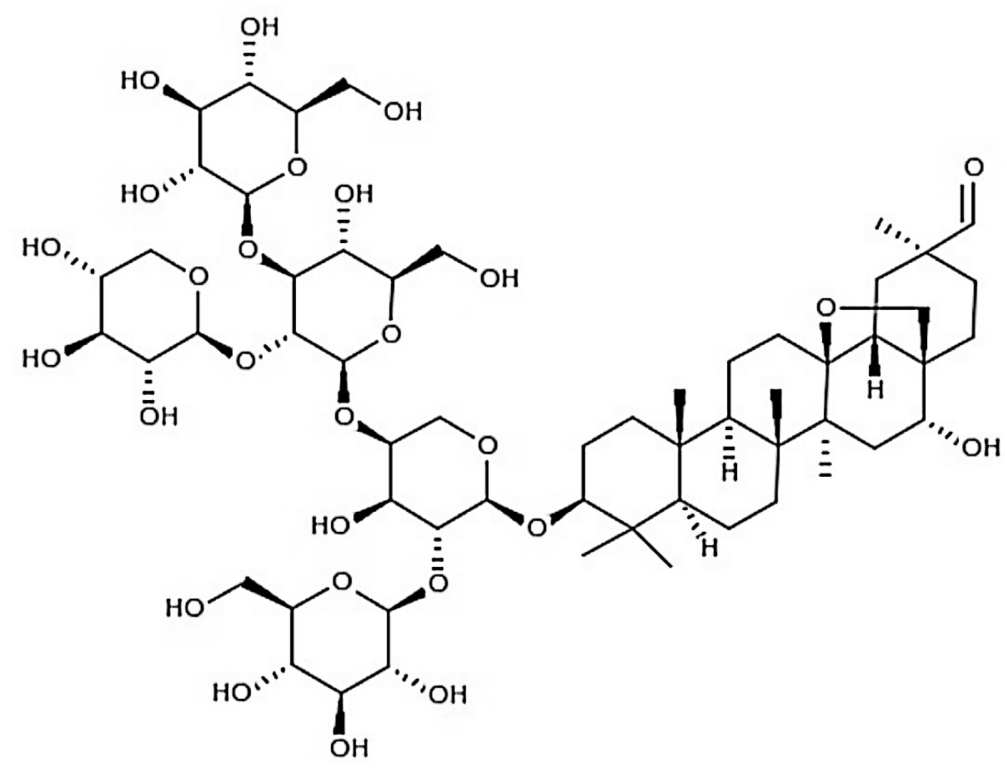

Figure 5. The chemical structure of cyclamin (toxic compound). 


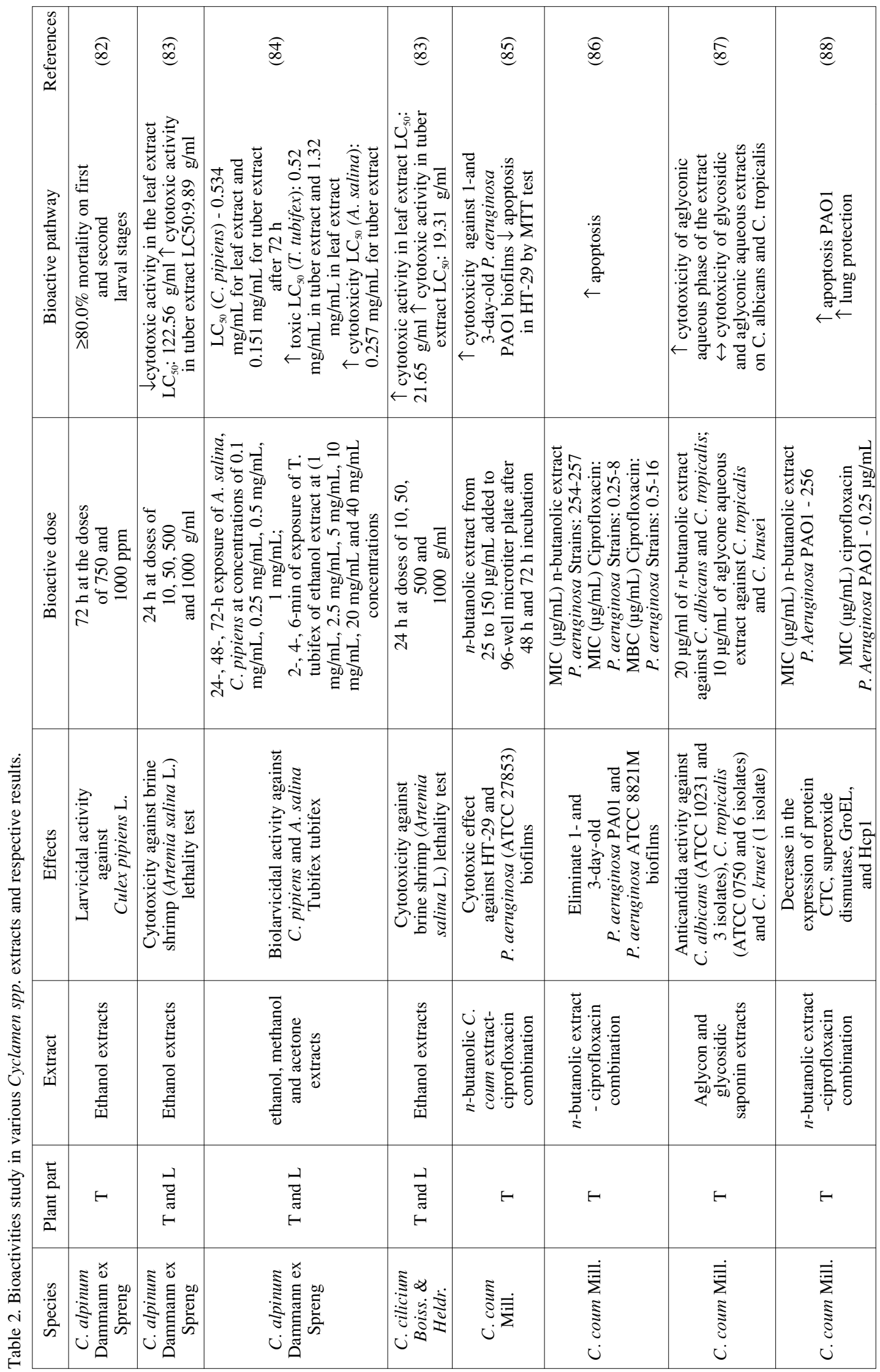




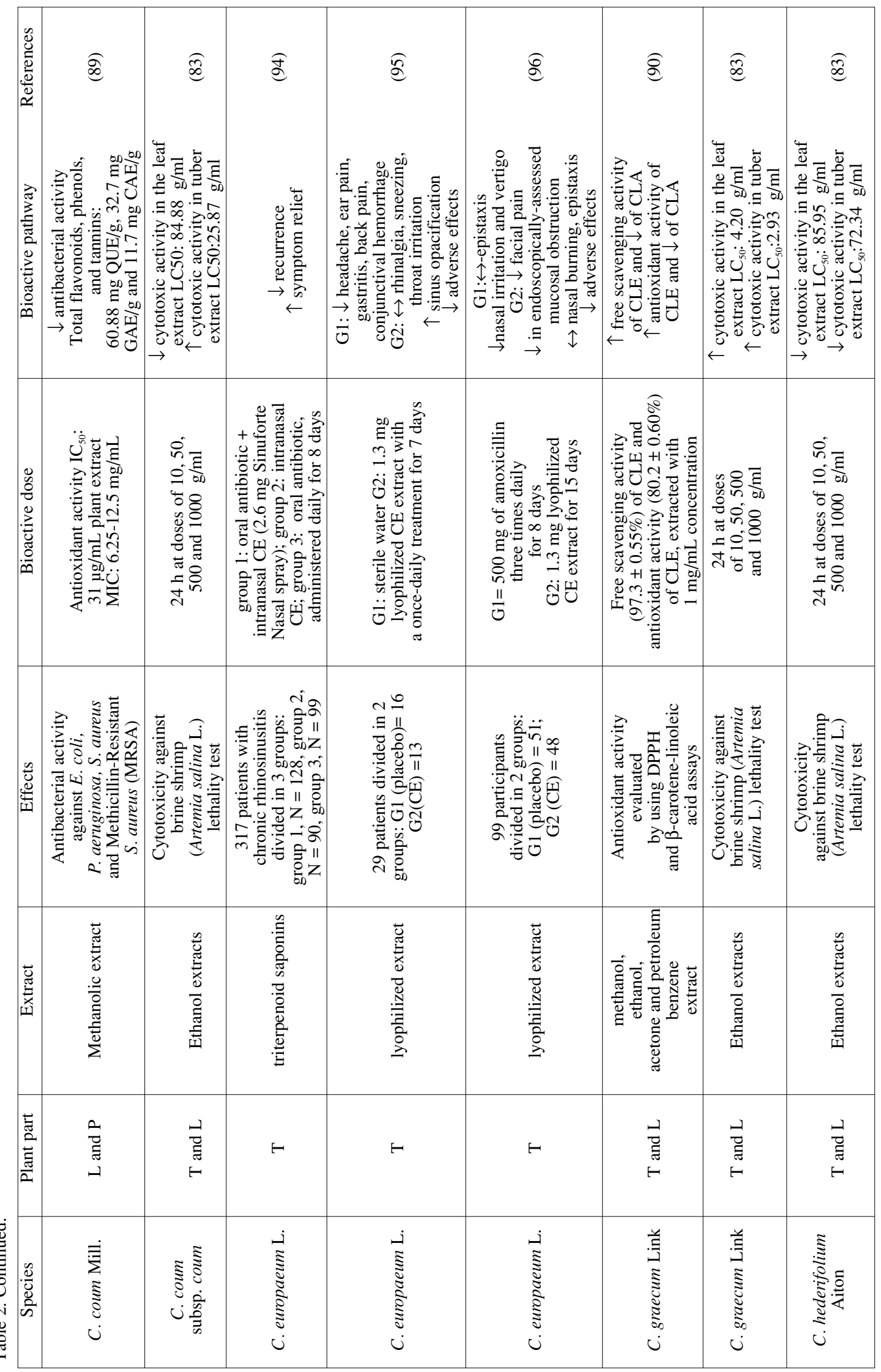




\begin{tabular}{|c|c|c|c|c|c|c|c|c|}
\hline 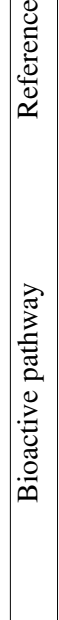 & 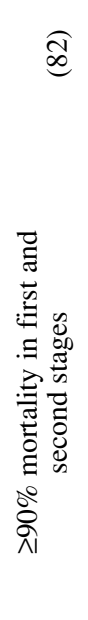 & 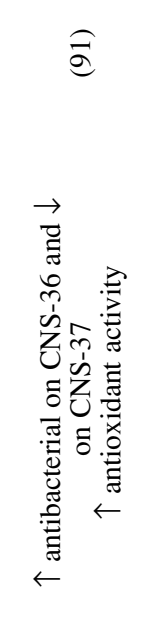 & 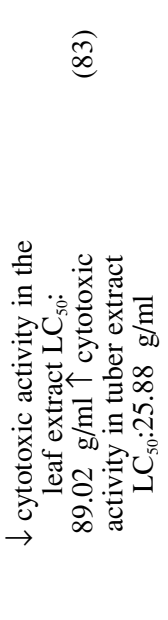 & $\begin{array}{l}\frac{0}{\hat{x}} \\
\stackrel{1}{1}\end{array}$ & 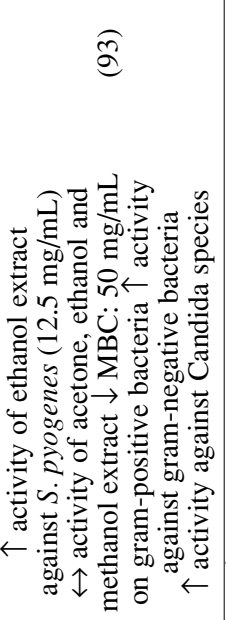 & 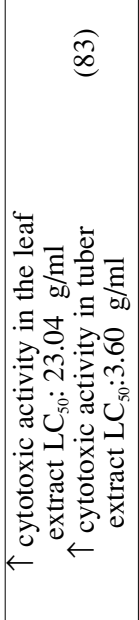 & 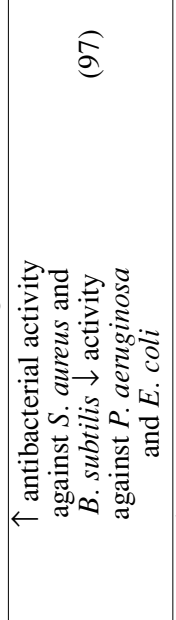 & 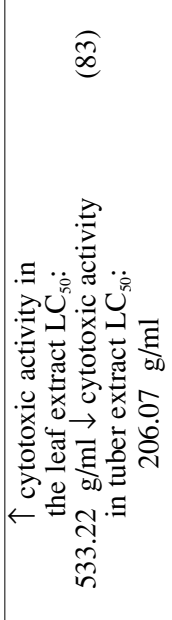 \\
\hline 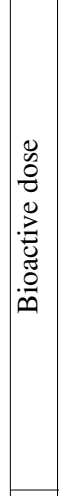 & 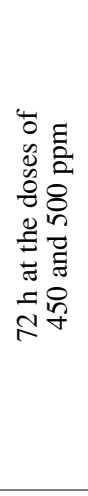 & 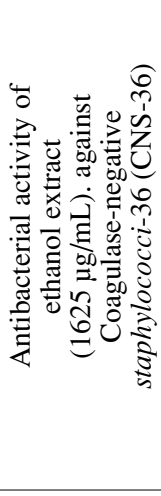 & 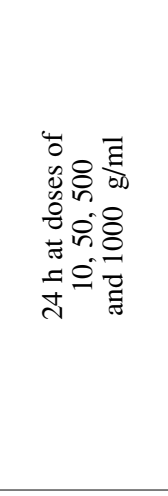 & 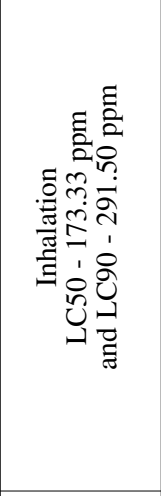 & 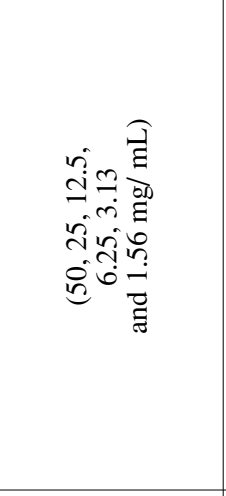 & 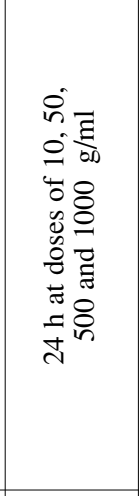 & 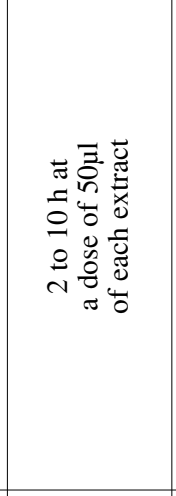 & 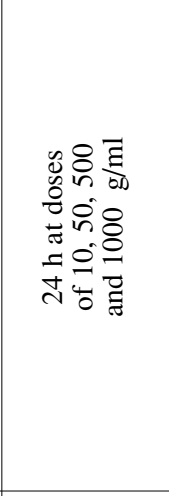 \\
\hline 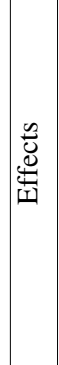 & 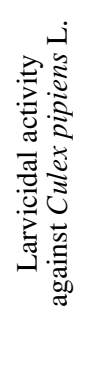 & 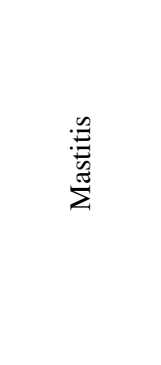 & 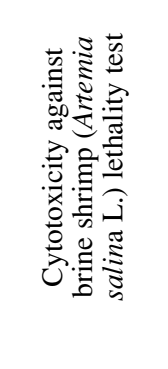 & 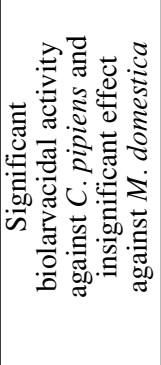 & 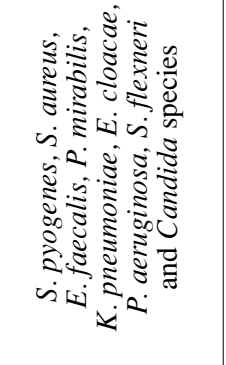 & 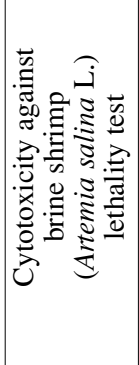 & 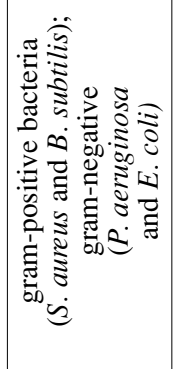 & 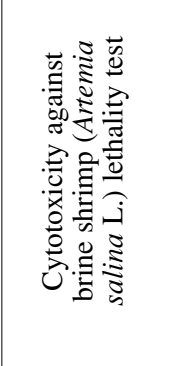 \\
\hline 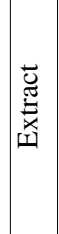 & 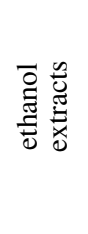 & 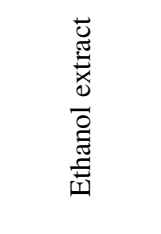 & 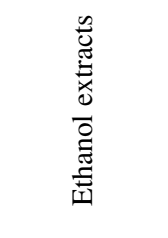 & 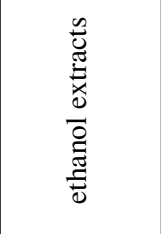 & 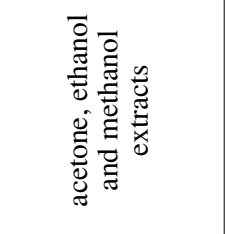 & 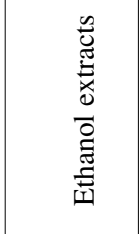 & 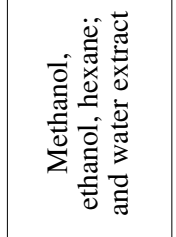 & 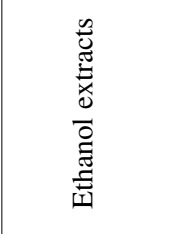 \\
\hline $\mid$ & $r$ & $H$ & 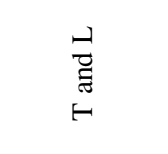 & $\begin{array}{l}\vec{\exists} \\
\vec{\Xi} \\
ت \\
ت\end{array}$ & $H$ & 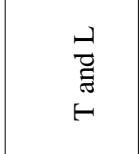 & $\mapsto$ & 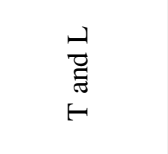 \\
\hline 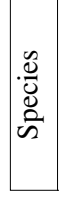 & 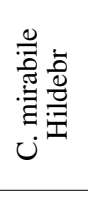 & 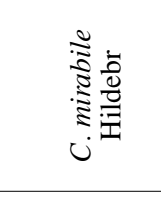 & 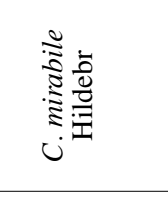 & 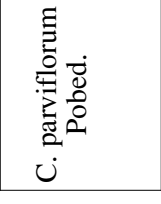 & 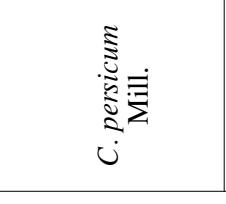 & 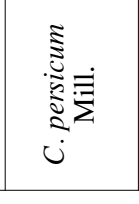 & 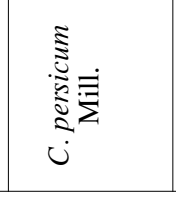 & 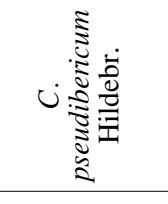 \\
\hline
\end{tabular}


Scientific data suggests that the risk of chronic diseases could be significantly reduced by antioxidants. This includes cancer, diabetes mellitus and heart disease. According to folk medicine several Cyclamen species were used for their therapeutic properties and early investigation resulted in the isolation of triterpenic saponins (70).

Çaliş et al., (1997b) isolated four saponins cyclaminorin, deglucocyclamin, cyclacoumin and mirabilin lactone from the tubers of $C$. coum Mill., which are used in Turkish folk medicine against infertility (71). In the same year, along with the saponins isolated from $C$. coum Mill., new compounds were found in $C$. mirabile Hildebr.: cyclamin, isocyclamin and mirabilin. They possess antibacterial and antifungal activities (79) (Table 2). Also, new triterpenoid saponins, coumoside A and coumoside $\mathrm{B}$, have been isolated from the whole plant of C. coum Mill. (73, 80).

All cyclamen plants are dangerous due to the toxic saponin known as cyclamin, contained in their fresh bulb, which is a white opaque substance that can absorb up to $45 \%$ water and become transparent (Fig. 5). Cyclamin is soluble in alcohol and turns brown on exposure to light. When dissolved in water, it produces foam by frothing test and by heating has the unique property of coagulation. Concentrated sulfuric acid colors cyclamin in purple red, which disappears with water addition.

Cyclamin is an irritant compound that causes gastroenteritis, bloody stools, dizziness, seizures and even death by asphyxiation. Studied by many physiologists, cyclamin was viewed merely as a local irritant (81).

Homeopathic essence of fresh tubers harvested in spring has shown potential for use against a variety of ailments, such as: headaches, common cold, digestive disorders, flatulence, colic attacks, chlorosis due to amenorrhea, rheumatism and gout without febrile events, cardiac neurosis, dysmenorrhea, worms, cramps and various skin diseases (81). Therefore, interactions with medical drugs should be avoided.

In old times, Cyclamen elegans Boiss. was used as a remedy in muscle spasms, headaches, and toothaches. Other medicinal plants, such as Atropa caucasica Kreyer. and Rosa damascena Mill.. were used as a treatment for these conditions. Also, $C$. elegans was used in spleen diseases, treatment replaced with Cucurbita pepo L. and Rumex confertus Wild. (98). However, their toxicity should be considered when other safe treatments are available. People all over the world deal with the toxic compounds (xenobiotics) of their region and the detoxi- cation mechanisms were adapted over generations to optimize the process. This was implying adaptations of the organism that include mutations, polymorphisms so that the detoxification process for each ethnicity in each region became more effective for its xenobiotics.

Thus, each ethnic group can consume with reasonable security the products of their geographic area, previously selected over generations, but the same is false when they cross ethnicities and consume products of different origins. Depending on the time point when a mutation occurred in the history of mankind, particular mutations may be unique for a certain population or show differences in their frequency when comparing ethnicities, leading to population-specific responses to drugs and other xenobiotics (100).

From what has been explained in the previous paragraph, the consumption recommendation of medicinal plants outside their area of origin for other ethnicities should be done with extreme caution. Despite all that we have just mentioned, the development of new drugs is absolutely transverse and has all these issues under consideration. Bacteria are increasingly resistant to antibiotics and the development of new drugs is very important. For Cyclamen mirabile Hildebr and Cyclamen trochopteranthum O. Schwarz. the antimicrobial activity was verified against different microorganisms: gram-negative (Escherichia coli), gram-positive (Bacillus subtilis) and fungus (Candida albicans). They have low antimicrobial activity but have significant antifungal activity (101).

Plant-based medicines prove to have an efficient role in the treatment of biofilm diseases and also have fewer side effects compared to synthetic medicines $(102,103)$. Cyclamen species are also well known for their medicinal properties and application in pharmaceutical industry.

Infections caused by Pseudomonas aeruginosa biofilm are the major causes of death in patients with cystic fibrosis (CF). The bacterial pathogen $P$. aeruginosa is one of the most significant agents involved in chronic lung infections in CF patients. Biofilm cells are known to be 1000 times more resistant to antibiotics compared to motile cells, allowing them to recolonize the host organs despite a series of antibiotic therapy.

C. coum Mill. extract revealed antibacterial activity against the growth of planktonic $P$. aeruginosa strains. The results showed that the combination of $n$-butanolic $C$. coum extract and ciprofloxacin inhibited $P$. aeruginosa biofilm development. Also, the $n$-butanolic $C$. coum extract showed an 
insignificant cytotoxic effect against HT-29 after 48 hours and 72 hours incubation (85).

The tubers of Cyclamen species are also known for their larvicidal activity. Therefore, the larvicidal activity of the tuber extracts isolated from two species of Cyclamen (C. mirabile Hildebr. and C. alpinum Dammann ex. Sprenger) against Culex pipiens L. (Diptera: Culicidae) was evaluated (82). Their results showed larval stage mortality after $12 \mathrm{~h}$ exposure and that $C$. mirabile was more effective than $C$. alpinum.

Table 3. Screening for anticancer potential of extracts and isolated compounds from Cyclamen spp.

\begin{tabular}{|c|c|c|c|c|c|}
\hline $\begin{array}{l}\text { Cyclamen spp. } \\
\text { used in the essay }\end{array}$ & $\begin{array}{c}\text { Plant } \\
\text { part }\end{array}$ & $\begin{array}{l}\text { Type of solvent extract } \\
\text { or bioactive substances }\end{array}$ & $\begin{array}{l}\text { Cancer cell } \\
\text { lines }\end{array}$ & Bioactivity & References \\
\hline $\begin{array}{l}\text { Cyclamen spp. } \\
\text { tubers }\end{array}$ & $\mathrm{T}$ & $\begin{array}{c}\text { Saponin alcoholic } \\
\text { extract }\end{array}$ & $\begin{array}{c}\text { Walker } \\
\text { carcinosarcoma } 256\end{array}$ & $\uparrow$ cytotoxicity & $(104)$ \\
\hline $\begin{array}{l}\text { Cyclamen spp. } \\
\text { and } \\
\text { Ardisia japonica }\end{array}$ & $\mathrm{T}$ & $\begin{array}{l}\text { Ethanolic extract } \\
\text { of cyclamin }\end{array}$ & $\begin{array}{l}\text { Bel-7402, HepG2 } \\
\text { and HL-7702 }\end{array}$ & $\begin{array}{c}\uparrow \text { cytotoxicity in Bel7402 } \\
\text { and HepG2; } \\
\text { in HL-7702 }\end{array}$ & $(137)$ \\
\hline $\begin{array}{l}\text { C. alpinum } \\
\text { Dammann ex } \\
\text { Spreng. }\end{array}$ & $\mathrm{T}$ & $\begin{array}{l}\text { Methanolic extract of } \\
\text { yclamin, desgluco- } \\
\text { ccyclamin I, mirabilin }\end{array}$ & $\begin{array}{l}\text { HCT } 116 \\
\text { and } \\
\text { HT-29 }\end{array}$ & $\begin{array}{c}\downarrow \text { cytotoxicity } \\
\text { in HCT } 116 \\
\text { and HT-29 }\end{array}$ & (138) \\
\hline $\begin{array}{l}\text { C. alpinum } \\
\text { Dammann ex } \\
\text { Spreng. }\end{array}$ & $\mathrm{T}$ & Ethanol extract & $\begin{array}{l}\text { Subcellular } \\
\text { fractions } \\
\text { of rat tissues }\end{array}$ & $\begin{array}{c}\uparrow \text { Hepatic CYP2E1, } \\
\text { CYP1A2 protein and } \\
\text { CYP2C6 mRNA level }\end{array}$ & (139) \\
\hline C. coum Mill. & $\mathrm{T}$ & $\begin{array}{c}\text { Cyclaminorin, } \\
\text { deglucocyclamin, } \\
\text { cyclacoumin, cyclamin, } \\
\text { isocyclamin, mirabilin } \\
\text { and mirabilin lactone }\end{array}$ & $\begin{array}{l}\text { Isolated Rat } \\
\text { Uterine } \\
\text { horns }\end{array}$ & $\uparrow$ uterocontractile activity & (79) \\
\hline C. coum Mill. & MP & $\begin{array}{l}\text { Methanol } \\
\text { and water } \\
\text { extracts }\end{array}$ & HeLa and H1299 & $\begin{array}{l}\text { 个 cytotoxicity } \\
\text { in HeLa and } \\
\text { NSCLC H1299 }\end{array}$ & $(140)$ \\
\hline $\begin{array}{c}C . \\
\text { hederifolium } \\
\text { Aiton. }\end{array}$ & $\mathrm{T}$ & $\begin{array}{l}\text { Hederifolioside } \\
\text { A, B, C, } \\
\text { D and E }\end{array}$ & $\begin{array}{l}\text { Hela, H-446, } \\
\text { HT-29, } \\
\text { U937 }\end{array}$ & $\downarrow$ apoptosis & $(108)$ \\
\hline $\begin{array}{l}\text { C. libanoticum } \\
\text { Hildebr. }\end{array}$ & $\mathrm{T}$ & $\begin{array}{c}\text { Triterpene saponins: } \\
\text { saxifragifolin B and cyclamin }\end{array}$ & $\begin{array}{l}\text { SK-BR-3, HT-29, } \\
\text { HepG2/3A, NCI- } \\
\text { H1299, BXPC-3, } \\
\text { 22RV1, DMEM }\end{array}$ & $\begin{array}{l}\downarrow \text { antioxidant } \\
\downarrow \text { citotoxicity }\end{array}$ & $(141)$ \\
\hline $\begin{array}{l}\text { C. persicum } \\
\text { Mill. }\end{array}$ & $\mathrm{T}$ & $\begin{array}{l}\text { Alcoholic } \\
\text { extract }\end{array}$ & $\begin{array}{l}\text { Human carcinoma of } \\
\text { the nasopharyn }\end{array}$ & $\uparrow$ apoptosis & $(142)$ \\
\hline $\begin{array}{l}\text { C. persicum } \\
\text { Mill. }\end{array}$ & $\mathrm{T}$ & $\begin{array}{l}\text { Active saponin- } \\
\text { fraction }\end{array}$ & $\begin{array}{c}\text { Walker } \\
\text { carcinosarcoma } 256\end{array}$ & $\uparrow$ apoptosis & $(142)$ \\
\hline $\begin{array}{l}\text { C. persicum } \\
\text { Mill. }\end{array}$ & $\mathrm{T}$ & $\begin{array}{c}\text { Triterpene saponins: } \\
\text { saxifragifolin B and cyclamin }\end{array}$ & $\begin{array}{l}\text { SK-BR-3, HT-29, } \\
\text { HepG2/3A, NCI- } \\
\text { H1299, BXPC-3, } \\
\text { 22RV1, DMEM }\end{array}$ & $\begin{array}{l}\downarrow \text { antioxidant } \\
\downarrow \text { cytotoxicity }\end{array}$ & $(141)$ \\
\hline $\begin{array}{l}\text { C. persicum } \\
\text { Mill. }\end{array}$ & $\mathrm{R}$ & Decoction (oral) & NS & $\downarrow$ cytotoxicity & $(143)$ \\
\hline $\begin{array}{l}\text { C. persicum } \\
\text { Mill. }\end{array}$ & $\mathrm{T}$ & $\begin{array}{l}\text { 3,5-Dithiahexanol 5,5- } \\
\text { dioxide, 1-(2- } \\
\text { Nitrophenyl) piperazine }\end{array}$ & NS & $\uparrow$ apoptosis & $(144)$ \\
\hline $\begin{array}{c}\text { C. } \\
\text { pseudibericum } \\
\text { Hildebr. }\end{array}$ & $\mathrm{T}$ & $\begin{array}{l}\text { n-butanolic saponin } \\
\text { extract dissolved in dimethyl } \\
\text { sulphoxide (DMSO) }\end{array}$ & $\begin{array}{l}\text { A549 } \\
\text { NSCLC } \\
\text { cell line }\end{array}$ & $\begin{array}{c}\text { IC50: } 41.64 \pm 2.35 \mu \mathrm{g} / \mathrm{mL} \\
\uparrow \text { cytotocicity on A549 cells } \\
\downarrow \text { number of A549 cells }\end{array}$ & $(145)$ \\
\hline $\begin{array}{c}C . \\
\text { purpurascens } \\
\text { Mill. }\end{array}$ & $\mathrm{T}$ & $\begin{array}{l}\text { Cyclamin, } \\
\text { isocyclamin and } \\
\text { methylcyclamin }\end{array}$ & L929 fibroblastic & $\begin{array}{l}\uparrow \text { cytotoxicity } \\
\downarrow \text { cell viability }\end{array}$ & $(146)$ \\
\hline
\end{tabular}

Note: NS - Not Specified; R - Roots; T - Tubers; MP - Multiple parts; $\uparrow$ - High; $\downarrow$ - Low 
Extracts of Cyclamen spp. tubers exhibited in vitro cytotoxic (104), spermicidal (105) and antimicrobial activities (106). It was reported to have sedative, purgative, abortive, laxative, vomiting emmenagogue and antihelmintic activity $(107,108)$.

A study published in 2014 evaluated the antioxidant and antibacterial activity of three crude extracts of C. africanum Boiss \& Reut.; namely, dichloromethane (DCM), methanol extract (ME) and methanol-water (MW), was evaluated (109). The results clearly show that the crude extracts of C. africanum Boiss \& Reut. only possess antioxidant activity, MW and DCM having a slight activity against $P$ seudomonas aeruginosa.

In a recent study, Dusen et al. (2016) evaluated the cytotoxic activity of the ethanol extracts of multiple Cyclamen L. taxa (C. alpinum Dammann ex Spreng., C. cilicium Boiss. \& Heldr., C. coum Mill. subsp. coum, C. graecum Link, C. hederifolium Aiton, C. mirabile Hildebr., C. persicum Mill., and C. pseudibericum Hildebr.) by using brine shrimp (Artemia salina $\mathrm{L}$.) lethality test and the $\mathrm{LC}_{50}$ values of the extracts were also determined.

The aim of a study (110) was to investigate the antibacterial activity of $C$. cilicium Boiss. \& Heldr., C. pseudibericum Hildebr. and $C$. hederifolium Aiton ethanol tuber extract against five bacterial fish pathogens, namely, V salmoninarum, S. epidermidis, L. garvieae, V. anguillarum, and Y.ruckeri, as well as their radical scavenging activity potentials. Their results showed that all the extracts exhibited moderate antibacterial activity in the order: $C$. cilicium $>$ C. pseudibericum $>$ C. hederifolium against four bacteria with the exception of $V$. anguillarum.

Around ten years ago, a new product obtained from plant extracts (C. europaeum), in the form of nasal spray (Nasodren ${ }^{\circledR}$ ) has been developed. It acts on mucous membranes of nasal and paranasal sinuses, activating physiological mechanisms for clearing nasal mucosa and facilitating drainage of the accumulated secretions $(111,112)$. An exploratory trial in patients $(n=29)$ with acute rhinosinusitis was conducted to evaluate the efficacy and safety of C. europaeum extract with the results of reduced sinus opacification compared with placebo treatment (95). In the same yea,r Pfaar et al. (2012) repeated the experiment with 99 patients. Both studies used placebo in the control group and the same dose $(1.3 \mathrm{mg} /$ day $)$ of $C$. europaeum lyophilized extract. Treatment duration in the studies was 15 days in Pfaar et al. (2012) and seven days in Ponikau et al. (2012). Uncertain results were observed in the former study regarding the improvement of nasal obstruction and edema. In 2018 Barua et al. reviewed the studies above mentioned concluding that patients who received $C$. europaeum rather than a non-active substance reported more side effects like nasal irritation, sneezing, and mild nasal bleeding, but with no major side effects.

In a study conducted by Evseenko et al. (2019) the $C$. europaeum tubers extract with concentration commonly used for human rhinosinusitis treatment was tested as a mucosal adjuvant in experimental intranasal immunization of guinea pigs with concentrated commercially available influenza trivalent vaccine and subsequent infection with influenza strain A/California/04/2009 H1N1pdm. Their results showed that dual intranasal immunization with vaccine compound consisting of $7.5 \mu \mathrm{g}$ of each hemagglutinin and $500 \mu \mathrm{g}$ of Cyclamen extract in $50 \mu \mathrm{L}$ induced reciprocal geometric mean titer (GMT) on day 21 after immunization 40 (5-640) against H1N1pdm; 43.20 (5-1280) against H3N2; 10.80 (5-80) against influenza B. The animals with hemagglutination inhibition antibody (HI) titers 1/80 against cell-derived antigen were completely protected against challenge with A/California/04/2009 H1N1pdm09.

Due to their saponin content, Cyclamen spp. have respiratory allergic $(111,112)$ and plant poisonings effects $(114,115)$. Also, they exert several allergenic effects $(114,116)$ and analgesic antiinflammatory effects $(115,117)$.

In general, the antioxidant activity of various solvent extracts from different parts (tuber and leaves) of $C$. mirabile Hildebr. were evaluated, using petroleum ether, acetone, methanol, and water. Also, other antioxidant properties were assessed, including free scavenging activity with 1,1diphenyl-2-picrylhydrazyl (DPPH), reducing power and total phenolic content (15).

Also, using synthetic preparations, it is likely to obtain similar bioactivities as for pure native compounds, as well as their analogs, through controlled structural adjustments formerly devised by medicinal chemistry studies. This will allow the discovery of new drugs, nevertheless, which is a challenging strategy due to the complex chemical structure of saponins, including various substituents, asymmetric carbons, and sugar moiety diversity. For several classes of compounds, the preparation of novel saponins is now available, including Quillaja saponins $(118,119)$ steroidal saponins (120-122) and oleanolic acid derivatives $(123,124)$ from various crude matrix sources.

Therefore, the application in the pharmaceutical industry and as a future source of dietary macroand microelements (125) proves to be achievable with further studies. 


\section{Anticancer potential of Cyclamen spp. con- stituents}

World Health Organization gave cancer as the second leading cause of death globally (1 in 6 deaths) responsible for an estimated 9.6 million deaths in 2018. They also emphasize that approximately $70 \%$ of deaths from cancer occur in low- and middle-income countries, while around one third of deaths from cancer are due to the 5 leading behavioral and dietary risks: high body mass index, low fruit and vegetable intake, lack of physical activity, tobacco use, and alcohol use (126). In addition to these data, the Institute for Health Metrics and Evaluation (IHME), an independent global health research center at the University of Washington, states cancer as the second leading cause of death in the USA (127). Therefore, the development of preventive and therapeutic strategies is crucial to invert this tendency.

Newman and Cragg (128) review the main drugs brought to the market between 1981 and 2014 and, from the 128 new anticancer medicines, only 20 were exclusively synthetic sourced. From the chemotherapeutic drugs now available and used in therapeutic protocols against cancer, some examples can be given as the already isolated camptothecin, paclitaxel and vincristine from Camptotheca acuminata Decne., Taxus brevifolia Nutt. and Catharanthus roseus (L.) G. Don., respectively (129). Due to the continuing expansion of plant-derived anticancer agents that have arrived at $30 \%$, this proves to be an important aspect in developing novel chemotherapeutics from natural sources (128-130).

The continuing development of plant-derived anticancer agents, which account $30 \%$, leads to the expansion of natural-sourced chemotherapeutics development (128-130). Drug development programs, particularly from endemic plant resources remain significantly important in discovering novel cytotoxic agents.

Therefore, an increasing interest in the pharmacological research section leans toward new molecular targets in anticancer drug design, such as different chemical compounds (Table 3) (131). The plant kingdom proves to be a significant resource of chemical constituents with cytotoxic and antitumor activities. This is due to plant biosynthesis of an assortment of structurally varied metabolites (132, 133). For instance, diverse plant sources from Turkey, including Cyclamen, are prone to act as efficiently anticancer agents $(134,135)$.

New resources of plant active compounds have encouraged researchers to develop new anticancer drugs. Throughout time, natural products have been used in preventing and treating various diseases, including cancer, therefore proving to be useful candidates in developing new anticancer remedies (136).

Also, in vitro cytotoxic effect of this new commercial plant extract from C. europaeum was investigated in L929 culture. At lower concentrations, in vitro cell viability was maintained, but at higher concentrations, the extract had a potentially toxic effect on cell viability and cell morphology (146).

In a recent study conducted by Stanojević and his colleagues (2018), the bioactive compounds and mineral composition of the aqueous extract from wild cyclamen tubers (Cyclamen purpurascens Mill.) were assessed. The most abundant components were found to be isocyclamin and desglucocyclamin I. It should be highlighted that these saponins exert cytotoxic activity on human colorectal cancer cells (HCT 116 and HT-29) (125).

C. coum Mill. is known to be a traditional medicinal plant in Turkey. Although this plant is used for decorative purposes, its medicinal properties are yet to be explored. There is little knowledge of the anti-tumor potential of this plant $(108,147)$. While this plant is commonly used as strictly ornamental, its medicinal properties in solid cancer cells have remained unexplored. Its anticancer properties and the probability of the extract to induce any cytotoxicity in solid cancer cells have not been previously thoroughly investigated. Therefore, the cytotoxic effects on HeLa and NSCLC H1299 were examined, with the result that Cyclamen extract induced cell death of HeLa and H1299 cells in a dose-dependent manner.

The capacity of the Cyclamen extract to induce apoptosis was also analyzed with the TUNEL assay. For the first time, it was reported that $C$. coum extract, an endemic plant for Turkey, Bulgaria, Georgia, and the Middle East, can be further investigated with the possibility of finding innovative anticancer compounds (140).

It is thought that the epithelial-to-mesenchymal transition (EMT) enhances malignant tumor progress. The transcriptional repressor zinc-finger E-box binding homeobox 1 (ZEB1) is a significant inducer of EMT in different human tumors, such as breast, lung, liver, pancreatic and ovarian cancers and has recently been shown to boost invasion by tumor cells $(148,140)$. Also, deregulation of miRNAs affects normal cell growth and development, leading to an assortment of diseases, such as cancer and cardiovascular disease $(149,150)$. The levels at which miRNAs are expressed in tumor tissues differs from those expressed in normal 
ones, suggesting that specific miRNAs could be used as biomarkers in evaluating disease prognosis (151).

In a different study, Karagur et al. (2018) investigated the cytotoxicity of $C$. pseudibericum Hildebr. saponin-rich tuber extract of different concentrations $(1,10,50,100,250,500,1000 \mu \mathrm{g} / \mathrm{mL})$ on the capacity of non-small cell lung cancer line A549 cells to proliferate, invade and migrate. Also, they examined the expression levels of multiple invasion-migration-related miRNAs to identify those which directly target ZEB1. Their results showed that the half-minimal $(50 \%)$ inhibitory concentration dose in the A549 cells was determined to be $41.64 \pm 2.35 \mu \mathrm{g} / \mathrm{mL}$. The overexpression of miRNA miR-200c hindered the EMT by increasing the expression of E-cadherin and decreasing the expression of both $\mathrm{N}$-cadherin and vimentin through the direct targeting of ZEB1.

These findings strongly suggest that the saponin-rich tuber extracts of multiple Cyclamen species may have considerable anti-cancer properties in several cancer types. Further studies are required to elucidate the molecular-based mechanism involved in the EMT process of the extracts along with the isolation and identification of active saponin components. The data are scarce but show a probable potential that could help in the design development of new cytotoxic agents using cyclamen compounds as models.

\section{Concluding remarks}

This review highlights the importance of Cyclamen species as ornamental pot plants and as a medicinal plant due to the content in bioactive compounds that can be used in many types of diseases. As described, the formation of organs and their development is controlled by key TFs. The ABCDE model identified in A. thaliana (L.) Heynh. is also responsible for flower phenotype in Cyclamen.

It is generally known that plants have wideranging medicinal properties and their secondary metabolites are used as specialty chemicals, such as drugs, insecticides, dyes, fragrances, and flavors. The focus of many studies are the extracts and isolated compounds which shown promising results in inducing apoptosis in different cell cultures, such as Walker carcinosarcoma 256, HeLa, NSCLC H1299 and cytotoxicity in Bel7402 and HepG2.

For example, the sesquiterpene hydrocarbons are very effective in both curing and protecting against numerous diseases. In addition, it was demonstrated that $C$. europaeum extract has moderate efficacy in treating chronic rhinosinusitis.
An important factor in identifying new medicine-candidate molecules involves scientific evaluation of traditional plant-based healing practices. This makes Cyclamen a perfect candidate to be explored for future therapeutic applications.

\author{
Abbreviations \\ 22RV1 prostate carcinoma \\ AMPK 5'adenosine-phosphate activated protein \\ kinase \\ ARE antioxidant response element \\ Bel7402 hepatocellular carcinoma cell line \\ BXPC-3 pancreatic carcinoma \\ CF cystic fibrosis \\ CITES Convention on International Trade in Endan- \\ gered Species of Wild Fauna and Flora \\ CNS-36 coagulase-negative staphylococci-36 \\ DCM dichloromethane \\ DMEM human fibroblasts \\ DPPH 2,2-diphenyl-1-picryl-hydrazyl-hydrate \\ ERK1/2 extracellular signal-regulated kinase \\ $\mathrm{H}-446$ human lung cancer cells \\ HCT 116 human colorectal carcinoma cell line \\ HeLa human cervical cancer cells \\ HepG2 human liver cancer cells \\ HepG2/3A hepatocellular carcinoma \\ HL-7702 Normal human hepatic cell line \\ HT-29 human colorectal adenocarcinoma cell line \\ ISPP isosalipurposide \\ L929 mouse fibroblast culture \\ ME methanol extract \\ MW methanol-water extract \\ NCI-H1299 lung carcinoma \\ Nrf2, NF-E2-related factor \\ NSCLC non-small cell lung cancer lines \\ SK-BR-3 breast adenocarcinoma cells \\ t-BHP tert-butyl hydroperoxide \\ TFs transcription factors \\ U937 human leukemia cells
}

\section{Conflict of interest}

The authors declare no conflicts of interest.

\section{REFERENCES}

1. Preda M.: Cyclamen, pp. 20-35, Ed. Ceres, Bucureşti 1971.

2. Grey-Wilson C.: Cyclamen (A guide for gardeners, horticulturists and botanists). pp. 182197 B.T. Bastsford, England 2015.

3. Anderson N.O. (Ed.)., Flower breeding and genetics: issues, challenges and opportunities 
for the 21st century. pp. 459-475, Springer Science \& Business Media, Minnesota 2006.

4. The Cyclamen Society - Species Images and description.https://www.cyclamen.org/plants/ species/ (accessed on 04.02.2019).

5. Schemske D.W., Bierzychudek P.: Evolution 61, 2528 (2007).

6. Arista M., Talavera M., Berjano R., Ortiz P.L.: J. Ecol. 101, 1613 (2013).

7. Mertens J., Pollier J., Bossche R.V., LopezVidriero I., Franco-Zorrilla J.M., Goossens A.: Plant Physiol. 170, 194 (2016).

8. De Sutter V., Vanderhaeghen R., Tilleman S., Lammertyn F., Vanhoutte I. et al.: Plant J. 44, 1065 (2005).

9. Vanden Bossche R., Demedts B., Vanderhaeghen R., Goossens A.: Methods Mol. Biol. 1011, 227 (2013).

10. Hong G.J., Xue X.Y., Mao Y.B., Wang L.J., Chen X.Y.: Plant Cell 24, 2635 (2012).

11. Schweizer F., Hasinger O.: Cyclamen purpurascens. The IUCN Red List of Threatened Species: e.T196750A2475951. org/10.http: //dx.doi.2305/IUCN.UK.2014-1.RLTS. T196750A2475951.en (2014).

12. Nakayama M., Tanikawa N., Morita Y., Ban Y.: Plant Biotechnol. 29, 215 (2012).

13. Takamura T., Sugimura T.: Tech. Bull. Fac. Agric. Kagawa Univ. 60, 30 (2008).

14. Mazouz W., Djeddi S.: J. Sci. Res. 1, 7 (2013).

15. Sarikurkcu C.: Afr. J. Biotechnol. 10, 831 (2011).

16. Ishizaka H.: Breeding science. 68, 25 (2018).

17. Ishizaka H., Kondo E., Kameari N.: Plant Biotechnol. 29, 201 (2012).

18. Çelemli Ö.G., Temizer I.K., Altýnözlü H.: Hacettepe J. Biol. Chem. 43, 105 (2015).

19. Ishizaka H., Uematsu J.: Japan. J. Breed. 40, 60 (1990), (In japanese).

20. Ishizaka H., Uematsu, J.: Japan. J. Breed. 42, 353 (1992).

21. Ishizaka H., Uematsu, J.: Euphytica 82, 31 (1995a).

22. Ewald A.: Plant Breed. 115, 162 (1996).

23. Ishizaka H.: Euphytica 91, 109 (1996).

24. Sibusawa N., Ogawa K.: Bull. Tokyo Agr. Exp. Stn. 27, 9 (1997).

25. Ishizaka H., Yamada H., Sasaki K.: Sci. Hortic. Amsterdam 94, 125 (2002).

26. Bowman J.L., Smyth D.R., Meyerowitz E.M.: Plant Cell. 1, 37 (1989).

27. Coen E.S., Meyerowitz E.M.: Nature 353, 31 (1991).

28. Latchman D.S.: Int. J. Biochem. Cell Biol. 29, 1305 (1997).
29. Ng M., Yanofsky M.F.: Nat. Rev. Genet. 2, 186 (2001)

30. Smaczniak C., Immink R.G., Angenent G.C., Kaufmann K.: Development 139, 3081 (2012).

31. Cao Y., Wang L., Zhao J., Zhang H., Tian Y. et al.: J. Mol. Neurosci. 59, 232 (2016).

32. Nadal E., Casadomé L., Posas F.: Mol. Cell Biol. 23, 229 (2003).

33. Tanaka Y., Oshima Y., Yamamura T., Sugiyama M., Mitsuda N. et al.: Sci. Rep. 3, 2641 (2013).

34. Castelán-Muńoz N., Herrera J., Cajero-Sánchez W., Arrizubieta M., Trejo C., Garcia-Ponce B. et al.: Front. Plant Sci. 10 (2019).

35. Osakabe Y., Osakabe K., Shinozaki K., Tran L.S.P.: Front. Plant Sci. 5, 86 (2014).

36. Zhu J.K.: Cell 167, 313 (2016).

37. Ishida T., Hattori S., Sano R., Inoue K., Shirano Y. et al.: Plant Cell 19, 2531 (2007).

38. Tanaka Y., Yamamura T., Terakawa T.: Plant Biotechnol. 28, 167 (2011).

39. Smaczniak C., Immink R.G.H., Angenent G.C., Kaufmann K.: Development 139, 3081 (2012).

40. Yan W., Chen D., Kaufmann K: Curr. Opin. Plant Biol. 29, 154 (2016).

41. Bartlett M.E.: Integr. Comp. Biol. 57, 1312 (2017).

42. Bloomer R.H., Dean C.: J. Exp. Bot. 68, 5439 (2017).

43. Whittaker C., Dean C.: Annu. Rev. Cell Dev. Biol. 33, 555 (2017).

44. Callens C., Tucker M.R., Zhang D., Wilson Z.A.: J. Exp. Bot. 69, 2435 (2018).

45. Theißen G., Kim JT., Saedler H.: J. Mol. Evol. 43, 484 (1996).

46. Shikata M., Narumi T., Yamaguchi H., Sasaki K., Aida R. et al.: Plant Biotechnol. 28, 189 (2011).

47. Gion K., Suzuri R., Shikata M., Mitsuda N., Oshima Y. et al.: Plant Biotechnol. 28, 149 (2011).

48. Narumi T., Aida R., Koyama T., Yamaguchi H., Sasaki K. et al.: Plant Biotechnol. 28, 131 (2011).

49. Ross-Ibarra J., Morrell P.L., Gaut B.S.: Proc. Natl. Acad. Sci. USA. 104, 8641 (2007).

50. Abbo S., Pinhasi Van-Oss R., Gopher A., Saranga Y., Ofner I., Peleg Z.: Trends Plant Sci. 19, 351 (2014).

51. Liu Z.X., Zhang D.D., Liu D., Li F.L., Lu H.: Plant Cell Rep. 32, 227 (2013)

52. Rijpkema A.S., Vandenbussche M., Koes R., Heijmans K., Gerats T.: Cell Dev. Biol. 21, 100 (2010). 
53. Smaczniak C., Immink R.G.H., Angenent G.C., Kaufmann K.: Development 139, 3081 (2012).

54. Mandel M.A., Gustafson-Brown C., Savidge B., Yanofsky M.F.: Nature 360, 273 (1992).

55. Jack T., Brockman L.L., Meyerowitz E.M.: Cell 68, 683 (1992).

56. Goto K., Meyerowitz E.M.: Genes Dev. 8, 1548 (1994).

57. Yanofsky M.F., Ma H., Bowman J.L., Drews G.N., Feldmann K.A., Meyerowitz E.M.: Nature 346, 35 (1990).

58. Favaro R., Pinyopich A., Battaglia R., Kooiker M., Borghi L. et al.: Plant Cell. 15, 2603 (2003).

59. Pinyopich A., Ditta G.S., Savidge B., Liljegren S.J., Baumann E. et al.: Nature 424, 85 (2003).

60. Pelaz S., Ditta G.S., Baumann E., Wisman E., Yanofsky M.F.: Nature 405, 200 (2000).

61. Ditta G., Pinyopich A., Robles P., Pelaz S., Yanofsky M.F.: Curr. Biol. 14, 1935 (2004).

62. Kevan P., Giurfa M., Chittka L.: Trends Plant Sci. 1, 280 (1996).

63. Vickery R.K.: Great Bas. Nat. 55, 177 (1995).

64. Kunze J., Gumbert A.: Behav. Ecol. 12, 447 (2001).

65. Rodríguez-Gironés M.A., Santamaría L.: PLoS Biol. 2, e350 (2004).

66. Rodríguez-Gironés M.A., Santamaría L.: P. Roy. Soc. Lond. B. Bio. 272, 187 (2005).

67. Veiga J.C., Menezes C., Venturieri G.C., Contrera F.A.: Apidologie 44, 324 (2013).

68. Ishizaka H.: Aroma Research 8, 46 (2007).

69. Jung Y., Hwang S., Sethi G., Fan L., Arfuso F., Ahn K.: Molecules 23, 2827 (2018).

70. Speroni E., Cervellati R., Costa S., Dall'acqua S., Guerra M.C. et al.: Phytother. Res. 21, 684 (2007).

71. Çaliş İ., Şatana M.E., Yürüker A., Kelican P., Demirdamar R. et al.: J. Nat. Prod. 60, 315 (1997b).

72. Webby R.F., Boase M.R.: Phytochemistry 52, 939 (1999).

73. Yayli N., Baltaci C., Zengin A., Kuçukislamoglu M., Genc H.: Phytochemistry 48, 881 (1998a).

74. Springob K., Kutchan T.M.: in Plant - Derived Natural Products: Synthesis, Functions and Applications, A.E. Osbourn and V. Lanzotti Eds. pp. 3-50, Springer Science, Dordrecht, Heidelberg, London, New York 2009.

75. Yendo A.C., de Costa F., Gosmann G., FettNeto A.G.: Mol. Biotechnol. 46, 94 (2010).

76. Mammadov R.: Secondary metabolites in seed plants. pp. 93-115, Nobel Pres, Ankara-Turkey (2014).
77. Ali-Shtayeh M.S., Jamous R.M., Al-Shafie J.H., Elgharabah W.A., Kherfan F.A. et al.: J. Ethnobiol. Ethnomed. 4, 3 (2008).

78. Morrissey J.P.: in Plant - Derived Natural Products: Synthesis, Functions and Applications, A.E. Osbourn and V. Lanzotti Eds., pp. 283-300, Springer Science, Dordrecht, Heidelberg, London, New York 2009.

79. Çaliş İ., Yürüker A., Tanker N., Wright A.D., Sticher O.: Planta Med. 63, 166 (1997a).

80. Yayli N., Baltaci C., Zengin A., Küçükislamoglu M., Genç H., Küçük M.: Planta Med. 64, 382 (1998b).

81. Fournier P.: Plantes Médicinales et Vénéneuses de France, Tome II: Consoude ŕ Melon, Connaissances et Mémoires Européennes pp 33-35. Société nationale d'horticulture de France 1999

82. Oz E., Koc S., Dusen O.D., Mammadov R., Cetin H.: Asian Pac. J. Trop. Dis. 6, 449 (2013).

83. Dusen S., Aydin C., Gul H.Y., Ozay C., Dusen O., Mammadov R.: Fresen. Environ. Bull. 25, 6224 (2016).

84. Turan M., Mammadov R.: Pharmacol. Pharm. 9, 100 (2018).

85. Abdi Ali A., Shafiei M., Shahcheraghi F., Saboora A., Ghazanfari T.: Biol. J. Micro. 3, 12 (2014).

86. Shafiei M., Ali A.A., Shahcheraghi F., Saboora A., Noghabi K.A.: Jundishapur J. Microbiol. 7 (2014).

87. Sajjadi S.T., Saboora A., Mohammadi P.: Curr. Med. Mycol. 2, 40 (2016).

88. Shafiei M., Abdi-Ali A., Shahcheraghi F., Vali H., Zahiri H. S., Noghabi K. A.: Appl. Biochem. Biotech. 182, 1444-1457 (2017).

89. Jaradat N.A., Al-Masri M., Hussen F., Zaid A.N., Ali I., Tammam A. et al.: Pharm. Sci. 23, 231 (2017).

90. Metin H., Aydin C., Ozay C., Mammadov R.: J. Chem. Soc. Pak. 35, 1332 (2013).

91. Okmen G., Erdal P., Isik D., Bayrak D.: Euro J. Exp. Biol. 4, 370 (2014).

92. Turan M., Mammadov R.: Biolarvacidal and Antioxidant Activity of Cyclamen parviflorum, The $3^{\text {rd }}$ International Symposium on EuroAsian Biodiversity 05-08 July, Minsk - Belarus 2017.

93. Al-zuabe M., Ismail Y., Hasan D., Alhrout H., Zeidaneen S. et al.: J. Pure. Appl. Microbiol. 13, 1 (2019).

94. Lopatin A.S., Ivanchenko O.A., Soshnikov S.S., Mullol J.: Acta Otorhinolaryngol. Ital. 38, 115 (2018).

95. Ponikau J.U., Hamilos D.L., Barreto A., Cecil J., Jones S.W. et al.: Laryngoscope 122, 1887 (2012). 
96. Pfaar O., Mullol J., Anders C., Hörmann K., Klimek L.: Rhinology 50, 37 (2012).

97. Alkowni R., Jodeh S., Hussein F., Jaradat N.: Pak. J. Pharm. Sci. 31 (2018).

98. Alakbarov F.U.: J. Herb. Pharm. 1, 35 (2001).

99. Ali-Shtayeh M.S., Jamous R.M., Al-Shafie J.H., Elgharabah W.A., Kherfan F.A. et al.: J. Ethnobiol. Ethnomed. 4, 3 (2008).

100. Kraemer S.D., Testa B.: Chem. Biodiver. 6, 1477 (2009).

101. Gündoğan T., Mammadov R., Ertem H., Makascı A.: Xim. Rastitel. Sirya. (Rusian). 2, 55 (2005).

102. Drenkard E.: Microb. Infect. 5, 1213 (2003).

103. Lewis K.: Antimicrob. Agents Chemother. 45, 999 (2001).

104. Kupchan S.M., Hemingway R.J., Knox J.R., Barboutis S.J., Werner D., Barboutis, M.A.: J. Pharm. Sci. 56, 603 (1967).

105. Primorac M., Sekulović D., Antonić S.: Pharmazie 40, 585 (1985).

106. Mahasneh A.M., El-Oqlah A.A.: J. Ethnopharmacol. 64, 271 (1999).

107. Moro P.A., Assisi F., Cassetti F., Bissoli M., Borghini R. et al.: Urban For. Urban Gree. 8, 179 (2009).

108. Altunkeyik H., Gülcemal D., Masullo M., Alankus-Caliskan O., Piacente S., Karayildirim T.: Phytochem. 73, 127 (2012).

109. Mazouz W., Djeddi S.: Adv. Environ. Biol. 8, 900 (2014).

110. Uluköy G., Cennet Ö.Z.A.Y., Mammadov R., Sayin Z.: Süleyman Demirel Üniversitesi Fen Bilimleri Enstitüsü Dergisi 22, 562 (2018).

111. Ianov I., Riazantsev S.V. Timchuk L.E.: Vestnik Otorinolaring. 4, 49 (2007).

112. Rybak A.A., Rybak A.A., Matveeva T.V., Nepri V.G.: Vestnik Otorinolaring. 3, 56 (2008).

113. Evseenko V.A., Kolosova N.P., Gudymo A.S., Maltsev S.V., Bulanovich J.A., Goncharova N.I. et al.: Arch. Virol. 164, 243 (2019).

114. Bolhaar S.T.H.P., Ginkel C.J.W.V.A.N.: Allergy 55, 411 (2000).

115. Kriukov A.I., Kunel'skaia N.L., Turovskii A.B., Artem'ev M.E., Ibragimova Z.S.: Vestnik Otorinolaring. 2, 33 (2007).

116. Ariano R., Mistrello G., Panzani R.: Eur. Ann. Allergy Clin. Immunol. 38, 90 (2006).

117. Spoerke D.G., Spoerke S.E., Hall A., Rumack B.H.: Vet. Hum. Toxicol. 29, 250 (1987).

118. Deng K., Adams M.M., Gin D.Y.: J. Am. Chem. Soc. 130, 5860 (2008).
119. Adams M.M., Damani P., Perl N.R., Won A., Hong F. et al.: J. Am. Chem. Soc., 132, 1939 (2010)

120. Wang H., Su F., Zhou L., Chen X., Lei P.: Bioorg. Med. Chem. Lett. 19, 2796 (2009).

121. Zhou W.B., Feng B., Huang H.Z., Qin Y.J., Wang Y.Z.: Carbohydr. Res. 345, 1752 (2010).

122. Wang H., Guo Y., Guan Y., Zhou L., Lei P.: Steroids 76, 8 (2011).

123. Yan M.C., Liu Y., Lu W.X., Wang H., Sha Y., Cheng M.S.: Carbohydr. Res. 343, 780 (2008).

124. Huang X., Cheng S., Du Y., Bing F.: Carbohydr. Res. 344, 1153 (2009).

125. Stanojević L., Cvetković D., Savić S., Petrović S., Cakić M.: Adv. Tech. 7, 5 (2018)

126. World Health Organization https://www.who. int/news-room/fact-sheets/detail/cancer (accessed on 31.03.2019).

127. James S.L., Abate D., Abate K.H., Abay S.M., Abbafati C. et al: Lancet 392, 1789 (2018).

128. Newman D.J., Cragg G.M.: J. Nat. Prod. 79, 629 (2016).

129. Pezzuto J.M.: Biochem. Pharmacol. 53, 121 (1997).

130. Abdulaev F.I.: Plant-derived agents against cancer, in: Gupta SK, Pharmacology and Therapeutics in the New Millennium, pp. 345354, Narosa Publishing House, New Delhi 2001.

131. Xia M., Wang D., Wang M., Tashiro S.I., Onodera S. et al.: J. Pharmacol. Sci. 95, 273 (2004).

132. Kim J.B., Koo H.N., Joeng H.J., Lyu Y.S., Park S.G. et al.: J. Pharmacol. Sci. 97, 138 (2005).

133. Chin Y.W., Balunas M.J., Chai H.B., Kinghorn A.D.: AAPS J. 8, 239 (2006).

134. Özmen A., Bauer S., Gridling M., Singhuber J., Krasteva S. et al.: Oncol. Rep. 22, 845 (2009).

135. Özmen A., Madlener S., Bauer S., Krasteva S., Vonach C.: Phytomedicine. 17, 55 (2010).

136. Kinghorn A.D., Farnsworth N.R., Doel Soejarto D. et al.: Pure App. Chem. 71, 1611 (1999).

137. Li Q., Deng L., Li W., Koike K.: Planta Med. 80, 409-414 (2014)

138. Mihci-Gaidi G., Ozbey S., Orhan I., Sener B., Miyamoto T. et al.: Planta Med. 76, 818 (2010)

139. Arslan S., Ozgun O., Celik G., Semiz A., Dusen O. et al.: Arch. Biol. Sci. Belgrade 63, 545 (2011). 
140. Yildiz M., Bozcuk H., Tokgun O., Karagur E.R., Akyurt O., Akca H.: Asian. Pac. J. Cancer Prev. 14, 5911 (2013).

141. El Hosry L., Di Giorgio C., Birer C., Habib J., Tueni M. et al.: Pharm. Biol. 52, 1134 (2014).

142. Oliver-Bever B.: Pharm. Biol. 11, 1665 (1971).

143. Jaradat N.A., Al-Ramahi R., Zaid A.N., Ayesh O.I., Eid A.M.: BMC Complement. Altern. Med. 16, 93 (2016).

144. Ibraheam I.A., Hussein H.M., Hameed I.H.: Int. J. Pharm. Qual. Assur. 8, 200 (2017).

145. Karagur E.R., Ozay C., Mammadov R., Akca H.: J. Nat. Med. 72, 686 (2018).
146. Beriat G.K., Akmansu Ş.H., Gürpinar Ö.A., Onur M.A., Alhan A.: Turk. Klinik. J. Med. Sci. 31, 287 (2011).

147. Indap M.A., Radhika S., Motiwale L., Rao, K.V.K.: Indian J. Pharm. Sci. 68, 465 (2006).

148. Yang M.H., Chen C.L., Chau G.Y., Chiou S.H., Su C.W. et al.: Hepatology 50, 1464 (2009).

149. Hwang H.W., Mendell J.T.: Br. J. Cancer 94, 776 (2006).

150. Esquela-Kerscher A., Slack F.J.: Nat. Rev. Cancer 6, 259 (2006)

151. Yanaihara N., Caplen N., Bowman E., Seike M., Kumamoto K. et al.: Cancer Cell 9, 189 (2006).

Received: 8.04.2019 